https://doi.org/10.5817/NR2020-1-7

\title{
Příspěvek k rusko-českým literárním vztahům
}

Большое собрание преданий, сказок и мифов западных славян. Москва: Эксмо, 2018, $784 \mathrm{c}$.

V roce, kdy si naše země připomněly sté výročí vzniku Československé republiky, vydalo významné moskevské nakladatelství Eksmo obsáhlý, reprezentativní soubor pověstí, pohádek a mýtů západních Slovanů v překladu Galiny Lifšic-Artemjevové

Předností publikace je, že vedle vlastních překladů uměleckých textů obsahuje také výběr teoretických statí - předmluvy K. J. Erbena k českým vydáním k „славянской хрестоматии“, „Предисловие к «Народному сообществу»“ а „Предисловие к «Чешским сказаниям»“Adolfa Weniga. Tyto studie podněcují čtenáře k zamyšlení nad významem přeložených, mnohdy opomíjených žánrů inspirovaných lidovou tvořivostí a vřazují je do širšího literárního i kulturního kontextu.

V podrobném úvodu „С молитвой о мире славянском“ spisovatelka a literární badatelka Galina Lifšic-Artemjeva, která je překladatelkou uměleckých textů a vynikající znalkyní české kultury, zavádí ruského čtenáře do vzdálené i méně vzdálené historie západních Slovanů, připomíná dějiny českého národa od přjetí křest’anství až do současnosti, akcentuje otázky dlouhotrvajícího boje za zachování českého jazyka, zmiňuje osobnosti, které se na záchraně češtiny významnou měrou podílely (Jungmann, Erben), poukazuje na některé momenty společné ruskému a českému národu. Předmluva končí upřímným, emotivním přáním - „modlitbou“ za jednotu slovanského světa.

První část knihy je věnována tvorbě básníka Karla Jaromíra Erbena, který podle názoru překladatelky natolik ovlivnil vývoj české literatury, že ve vztahu k jeho dílu lze použít parafrázované ruské okřídlené rčení „Все мы вышли из гоголевской Шинели“ - „Все мы родом из баллад и сказок Эрбена“. Uměleckým překladovým textům předchází Erbenova biografie a informace o jeho badatelské a překladatelské činnosti. Připomenuty jsou rovněž dřívější ruské překlady českého básníka a neúplný překlad Kytice, jehož autorem je N. N. Asejev. Ten také použil Jiří Klapka v trojjazyčné publikaci (čeština, slovenština, ruština), kterou jeho zásluhou vydala Česká asociace rusistů v roce 2011 u př́ležitosti 200. výročí Erbenova narození a právě jubilejní vydání bylo inspirací k novým překladům balad. tyto překlady jsou velmi zdařilé, překladatelka se snaží zachovat „věrnost originálu“, jen zřídka používá výrazy z ruského prostředí (např. v baladě Štědrý večer „пироги хозяину“ (čes. „hospodáři štědrovku“) nebo opakování v českém originále „toč se, toč můj kolovrátku“ velmi případně nahradila „моя прялочка, крутись-вертись“. Výraz advent („рождественский пост“) nahradila 
opisným spojením „Рождество, скорее нам явись“. Asejev nakládá s originálem volněji, což je patrné i z níže uvedených úryvků z balady Štědrý večer:

Пироги хозяину, / Коровам корм в кормушку; / Петуху чесноку, / Гороху его дружке. / Хозяину - хлеба, / Коровам - кормежку, / Петух - чеснок любит, / Курам - горсть горошку.

G. M. Lifšic-Artemjeva, na rozdíl od N.N. Asejeva, vzala v úvahu, že věštění spojené s Vánocemi obsažené v baladě Štědrý večer bylo rozšířené také v ruském prostředí. Využila př́ibuznosti ruského a českého textu, proto zastaralý výraz štědrovka nahradila výrazem „piroh“, jenž se u ruského čtenáře lehce asociuje s vlastním folklorním textem. Zároveň však nic nezůstala dlužna Erbenově originálu, zachovala rytmus i poetičnost veršů.

Dále jsou v knize uvedeny překlady pohádek. Kromě tradičních lidových pohádek zaznamenaných K.J. Erbenem a B. Němcovou jsou zařazeny také pohádky z moravských regionů (Valašsko, Lašsko) zapsané Karlem Dvořáčkem a Petrem Martinem, jejichž vydání je datováno léty $\mathrm{v}$ době druhé světové války $(1941,1943)$. Jména sběratelů i jejich texty jsou málo známé i českému čtenáři. Při výběru pohádek Erbena a Němcové překladatelka rozlišuje: uvádí ty, které byly inspirovány ústní tvořivostí jiných západoslovanských národů. Dokládá tak Erbenův hluboký zájem o folklorní tvorbu Slovanů - Lužických Srbů, Poláků a Kašubů a upozorňuje na využití slovenských folklorních zdrojů v pohádkách B. Němcové.

Poslední část knihy obsahuje překlady různorodých známých i méně známých českých pověstí, které zapsal spisovatel Adolf Wenig.

Závěrečné části knihy obsahují řadu doplňujících materiálů; badatelka v nich např. upozorňuje na motivy a témata, které se objevují v Kytici a s nimiž se rovněž setkáváme $\mathrm{v}$ různých žánrech lidové tvořivosti u jiných slovanských národů.

Reprezentativní knihu představila v Ruském kulturním centru v Plzni a v Ruském středisku vědy a kultury v Praze.

Jana Sováková

\section{Bibliografie:}

Bol'šoje sobranije predanij, skazok i mifov zapadnych slavjan. (2018). Moskva. 